\title{
Milk losses associated with somatic cell counts by parity and stage of lactation
}

\author{
Juliano L. Gonçalves, ${ }^{*}$ Roger I. Cue,† Bruno G. Botaro,‡ José A. Horst,§ Altair A. Valloto,§ \\ and Marcos V. Santos*1 \\ *Department of Animal Nutrition and Production, School of Veterinary Medicine and Animal Sciences, University of São Paulo (USP), \\ Pirassununga, São Paulo, 13635-900, Brazil \\ †Department of Animal Science, Macdonald Campus, McGill University, H9X 3V9, Quebec, Canada \\ fLivestock Systems Research Department, Animal \& Grassland Research and Innovation Centre, Teagasc, Moorepark, Fermoy, Co. Cork, \\ P61 C996, Ireland \\ §Associação Paranaense de Criadores de Bovinos da Raça Holandesa (APCBRH), Curitiba, Paraná, 81200-404, Brazil
}

\section{ABSTRACT}

The reduction of milk production caused by subclinical mastitis in dairy cows was evaluated through the regression of test-day milk yield on log-transformed somatic cell counts (LnSCC). Official test-day records $(\mathrm{n}=1,688,054)$ of Holstein cows $(\mathrm{n}=87,695)$ were obtained from 719 herds from January 2010 to December 2015. Editing was performed to ensure both reliability and consistency for the statistical analysis, and the final data set comprised 232,937 test-day records from 31,692 Holstein cows in 243 herds. A segmented regression was fitted to estimate the cutoff point in the LnSCC scale where milk yield started to be affected by mastitis. The statistical model used to explain daily milk yield included the effect of herd as a random effect and days in milk and LnSCC as fixed effects regressions, and analyses were performed by parity and stage of lactation. The cutoff point where milk yield starts to be affected by changes in LnSCC was estimated to be around 2.52 (the average of all estimates of approximately 12,400 cells $/ \mathrm{mL}$ ) for Holsteins cows from Brazilian herds. For first-lactation cows, milk losses per unit increase of LnSCC had estimates around $0.68 \mathrm{~kg} / \mathrm{d}$ in the beginning of the lactation [ 5 to $19 \mathrm{~d}$ in milk (DIM)] $0.55 \mathrm{~kg} / \mathrm{d}$ in mid-lactation (110 to $124 \mathrm{DIM}$ ), and $0.97 \mathrm{~kg} / \mathrm{d}$ at the end of the lactation (289 to 304 DIM). For second-lactation cows, milk losses per unit increase of LnSCC had estimates around $1.47 \mathrm{~kg} / \mathrm{d}$ in the beginning of the lactation ( 5 to 19 DIM), $1.09 \mathrm{~kg} / \mathrm{d}$ in mid-lactation (110 to 124 DIM), and $2.45 \mathrm{~kg} / \mathrm{d}$ at the end of the lactation (289 to 304 DIM). For thirdlactation cows, milk losses per unit increase of LnSCC had estimates around $2.22 \mathrm{~kg} / \mathrm{d}$ in the beginning of the

Received June 4, 2017.

Accepted December 21, 2017.

${ }^{1}$ Corresponding author: mveiga@usp.br lactation (5 to $19 \mathrm{DIM}), 1.13 \mathrm{~kg} / \mathrm{d}$ in mid-lactation (140 to $154 \mathrm{DIM}$ ), and $2.65 \mathrm{~kg} / \mathrm{d}$ at the end of the lactation (289 to 304 DIM). Daily milk losses caused by increased LnSCC were dependent on parity and stage of lactation, and these factors should be considered when estimating losses associated with subclinical mastitis.

Key words: subclinical, mastitis, test day record, milk loss

\section{INTRODUCTION}

Milk losses (ML) associated with high SCC at cow level are a consequence of the inflammatory response of the bovine mammary gland against infections caused by mastitis-causing pathogens (Hortet and Seegers, 1998; Seegers et al., 2003). Estimation of these losses have been systematically assessed (Halasa et al., 2007, 2009; Hogeveen et al., 2011; Huijps et al., 2008), providing the dairy industry with pivotal approximation on the costs incurred to keep high-SCC cows in the herd (Geary et al., 2012). The majority of these assessments were based on the assumption that a rise in the individual SCC above a threshold value of 200,000 cells/mL (Bradley and Green, 2005; IDF, 2013; Schukken et al., 2003) is an indication that an infection has occurred.

Not surprisingly, animals recording SCC >200,000 cells/mL at test day are prone to experience ML, the extent of which is dependent upon the parity and stage of lactation of the animal (Hagnestam-Nielsen et al., 2009; Hand et al., 2012). How much of this increase from individual SCC still kept below the 200,000 cells/ $\mathrm{mL}$ threshold (IDF, 2013) is, in fact, reflected in ML from high-yielding cows is a key question yet not entirely addressed (Boland et al., 2013; Green et al., 2006); thus, animals potentially underperforming go unnoticed by the herd owner provided that the bulk tank SCC is $\sim 200,000$ cells/mL (van Asseldonk et al., 2010). This 
quantification requires a comprehensive understanding on the relationship held between the SCC and the milk yield at cow level (Hand et al., 2012).

Previous studies evaluated different SCC thresholds at which milk yield starts to be affected by changes in cell counts, taking parity and stage of lactation into consideration (Dürr et al., 2008). In Canada, Dürr et al. (2008) reported that losses were first observed when SCC of Holsteins and Ayrshires were $>7,400$ cells $/ \mathrm{mL}$. However, those associations (Dürr et al., 2008) may not be relatable to distinct populations of dairy cows, given the potential influence of geographic factors over different population of dairy cattle (Boland et al., 2013). Therefore, given that a direct relationship between SCC $<200,000$ cells/mL and ML exists (Dürr et al., 2008), and that this depends on both the cow's parity and the stage of lactation (Hand et al., 2012), our primary hypothesis was that the milk yield of Brazilian Holstein cows was not affected until the SCC level exceeded a certain level. However, after reaching a given hypothesized threshold, individual milk yield would be affected as SCC increases. Hence, the aims of our study were to estimate (1) the threshold at which the association between SCC and milk yield is observed; (2) the magnitude of the effect of SCC on milk yield from Holstein cows in Brazilian dairy herds using test-day records; and (3) whether the association between SCC and milk yield varies according to parity and stage of lactation of cows.

\section{MATERIALS AND METHODS}

\section{Data}

Test-day records were obtained from the Associação Paranaense de Criadores de Bovinos da Raça Holandesa (APCBRH), which is the official Holstein milk recording organization of State of Paraná, Curitiba, Brazil. The data set included information from lactating Holstein cows from January 2010 to December 2015. Editing was performed to ensure both reliability and consistency for the statistical analysis. To be included in the data set, test-day records were required to have fat content between 2.5 and $6.5 \%$, protein content between 2.5 and $5.5 \%$, lactose content between 3.5 and $6 \%$, TS content between 8.5 and $14.5 \%$, SCC between 0 and 1,000,000 cells $/ \mathrm{mL}$, and milk yield between 2 and $70 \mathrm{~kg}$, as described by Dürr et al. (2008). Test-day recordings $\geq 305 \mathrm{~d}$ in milk were excluded from analysis. We also checked and imposed constraints on the ages at calving (by parity) to ensure that parities were consistent with sensible ages at calving. Twenty stages of lactation groups were defined (stage $1=\mathrm{d} 5$ to 20 , stage $2=\mathrm{d} 21$ to $35, \ldots$, stage $20=\mathrm{d} 291$ to 304$)$. To allow the inclusion of a random herd-test-day (HTD) effect in the statistical model, we imposed a minimum of 100 records per herd and the constraint that within each parity-stage group the HTD needed $\geq 4$ records to be kept for subsequent analyses. The number of testday records excluded and retained at each step of the editing and the reasons for the exclusions are shown in Table 1. Initial analyses of records from parities greater than 3 (where there were low numbers of animals) gave parameter estimates that were unreliable (no SE of the parameter estimates, analyses did not converge, or the calculated parameters were nonsensical); consequently, only parities 1,2 , and 3 were retained for statistical analyses. The constraint of $\geq 4$ records for each parity-stage-herd cluster removed a substantial number of records; however, it was necessary to have at least 4 records per cluster, as we were fitting random effects of $a, b$, and c to each cluster. After editing, the final data set comprised 232,937 test-day records from 31,692 Holstein cows in 243 herds from January 2010 to December 2015. Descriptive statistics of records used herein are presented in Table 2. Descriptive statistics of both kept and eliminated data sets showed that records used for analysis were representative of the Brazilian dairy cow population in the period studied (Cunha et al., 2008).

\section{Statistical Analysis}

To assess the aim of this study, statistical analyses were performed separately by parity and by stage of lactation. The majority of herds evaluated were monthly tested assisted by a milk recorder; hence, within one 15 -d stage of lactation there was only 1 herd-test visit. Therefore, apart from any surprise spot-test retests of herds, only 1 record per cow per lactation stage was used to avoid any issues of repeated records per cow. To avoid problems of unlikely, occasional spot herd retest and the inclusion of individual repeated measurements within the same parity-stage interval, only the first record in a herd-parity-stage was kept for analysis.

To assess the SCC threshold at which a milk yield drop occurs, the approach adopted here was to estimate the threshold from the data by fitting a segmented regression (as per Dürr et al., 2008). As healthy cows maintain low cell counts in milk (Capuco et al., 2003), we hypothesized that milk yield was not affected by increasing SCC level up to some (unknown) level of SCC. After reaching this cutoff point, milk yield would be affected as SCC increases. This required the estimation of 3 parameters: the intercept $(a)$, the cutoff (threshold) point where ML starts $(c)$, and the regres- 
sion coefficient of milk yield on SCC $(b)$, for values of SCC above the cutoff. The basic statistical model used to analyze data were as follows.

[1] For observations where the LnSCC was greater than the cutoff,

$$
\begin{aligned}
\mathrm{X}_{\mathrm{ij}}=\mu+ & (1 \mid \mathrm{HTD})_{\mathrm{i}}+\beta(\operatorname{LnSCC}-c)_{\mathrm{ij}} \\
& +\beta_{1}(\mathrm{DIM})_{\mathrm{ij}}+\varepsilon_{\mathrm{ij}} ;
\end{aligned}
$$

[2] for observations in which the LnSCC was less than or equal to the cutoff, the model was

$$
\mathrm{X}_{\mathrm{ij}}=\mu+(1 \mid \mathrm{HTD})_{\mathrm{i}}+\beta_{1}(\mathrm{DIM})_{\mathrm{ij}}+\varepsilon_{\mathrm{ij}},
$$

where $\mathrm{X}_{\mathrm{ij}}$ is the milk yield at test day of the jth cow in the ith HTD; $\mu$ is the mean milk yield of the population; $(1 \mid \text { HTD })_{i}$ is the random effect of HTD (data from 2010 to 2015); LnSCC is the natural logarithm of the SCC at test day [e.g., $\mathrm{SCC}=100$ is equivalent to $\mathrm{LnSCC}$ of $5.3=100(\times 1,000)=100,000$ cells $/ \mathrm{mL}] ; c$ is the cutoff as described above; $\mathrm{DIM}_{\mathrm{ij}}$ is days in milk of the jth cow in the ith HTD; $\beta$ and $\beta_{1}$ are the respective regression coefficients; and the error term is $\varepsilon \sim N\left(0, \sigma^{2} \mathbf{I}\right)$, where $\sigma^{2}$ is the residual variance and $\mathbf{I}$ is the identity matrix. The DIM interval within each stage were only $15 \mathrm{~d}$. Over this short time interval, a linear regression was sufficient to adequately explain the effects of DIM; a quadratic effect of DIM was not statistically significant.

The statistical analyses were carried out using the NLMIXED procedure of SAS, which accommodates nonlinear mixed models and allows fitting segmented regressions (version 9.3; SAS Institute Inc., Cary, NC). We tried fitting a quadratic term for LnSCC, but only 3 cases (parity-stages) out of the 6 parities and 20 stages per parity gave converged estimates. Consequently, only the linear regression of milk yield on LnSCC was used.

\section{Postanalysis Calculations}

To describe the trend of the linear regression coefficients of daily milk yield on LnSCC over the course of each lactation, the regression coefficient estimates for the 20 stages defined here were, in turn, used as data points in a weighted regression on DIM (by parity), weighted by the inverse of their sampling variance, as per Dürr et al. (2008). This allowed an estimate of a milk loss regression coefficient appropriate to any given DIM within a parity and not just to the 20 stages of lactation classes. The weighted regressions also provided a means of testing differences between linear regression coefficients of daily milk yield on LnSCC obtained for each parity to see whether the estimates across parities could be pooled or not. An ANOVA showed that the regressions within parities were not homogeneous, and hence have not been pooled; results are shown separately for each parity. The GLM procedure of SAS was used to carry out the weighted regressions (version 9.3; SAS Institute Inc.). The expected daily ML distributed in different groups of SCC according to the parity-stage of lactation combination were calculated. The actual ML for individual cows may be estimated by applying

\begin{tabular}{|c|c|c|c|}
\hline $\begin{array}{l}\text { Excluded test-day records based } \\
\text { on the following criteria }\end{array}$ & $\begin{array}{l}\text { Initial number of records } \\
\text { at each edit step }\end{array}$ & $\begin{array}{l}\text { Number of test-day } \\
\text { records retained }\end{array}$ & $\begin{array}{l}\text { Number of test-day } \\
\text { records excluded }\end{array}$ \\
\hline Breeds other than Holsteins & $1,688,054$ & $1,530,276$ & 157,778 \\
\hline$\geq 305 \mathrm{~d}$ & $1,530,276$ & $1,212,674$ & 317,602 \\
\hline$\overline{\mathrm{S} C C}=0$ & $1,212,674$ & $1,200,086$ & 12,588 \\
\hline$>1,000,000$ cells $/ \mathrm{mL}$ & $1,200,086$ & $1,083,679$ & 116,407 \\
\hline Parity $\geq 7$ & $1,083,679$ & $1,068,729$ & 14,950 \\
\hline Inconsistent lactation length & 935,665 & 932,679 & 2,986 \\
\hline Age at calving criteria limits by parity & 932,679 & 820,011 & 112,668 \\
\hline Parity $1(21 \leq$ age at calving $<40)$ & 368,213 & 328,337 & 39,876 \\
\hline Parity $2(33 \leq$ age at calving $<55)$ & 260,592 & 221,149 & 39,443 \\
\hline Parity $3(43 \leq$ age at calving $<75)$ & 158,806 & 139,608 & 19,198 \\
\hline Parity $4(54 \leq$ age at calving $<95)$ & 85,387 & 76,636 & 8,751 \\
\hline Parity $5(65 \leq$ age at calving $<115)$ & 41,192 & 37,636 & 3,556 \\
\hline
\end{tabular}
the equation

Table 1. Editing criteria and number of records retained and excluded 


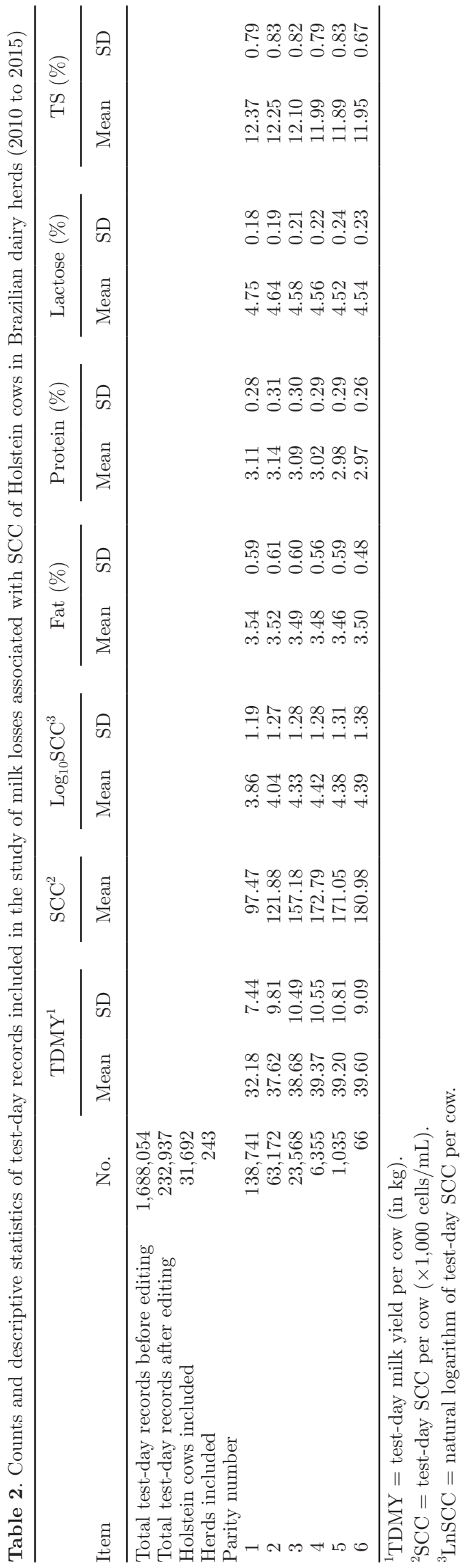

$$
\mathrm{ML}=(\mathrm{LnSCC}-c) \times \mathrm{EML},
$$

where ML is the milk loss $(\mathrm{kg})$ for a given cow, LnSCC is the actual SCC on the natural logarithm scale in that cow's milk, cutoff $c$ is the point in the log scale where losses start, and EML is the expected milk loss per unit increased in LnSCC according to parity-stage of lactation combination. For example, Figure 1, parity 1 and stage 1, which corresponds to DIM 5 to 19 , had threshold $(c)=1.01$; from Table 2 , parity 1 and stage 1 (d 5 to 19), the expected milk loss (EML, b) was 0.68. An SCC of 100,000 corresponds to LnSCC of 4.61; thus, the ML from parity 1 and stage 1 corresponds to (4.61 $-1.01) \times 0.68=2.44 \mathrm{~kg} /$ cow per day. Similarly, from Figure 1, parity 1 and stage 2 (d 20 to 34 ) had threshold $(c)=1.58$. From Table 2 , parity 1 and stage $2(\mathrm{~d} 20$ to 34 ), the expected milk loss (EML, b) was 0.64. An SCC of $100,000 \mathrm{cell} / \mathrm{mL}$ corresponds to $\mathrm{LnSCC}$ of 4.61 ; thus, the ML from parity 1 and stage 2 corresponds to $(4.61-1.58) \times 0.64=1.93 \mathrm{~kg} /$ cow per day. We can do likewise for the other stages corresponding to parity 1 and then the average ML over these 20 stages to get $1.75 \mathrm{~kg} / \mathrm{cow}$ per day (Table 3), and similar for parity 2 and 3 . The greater the LnSCC, the greater the ML, expressed both in kilograms and percentage.

\section{RESULTS}

\section{Cutoff Point}

The estimate of the cutoff point $(c)$, where ML was associated with change of LnSCC start for different parity-stage of lactation combinations of Holstein cows from Brazil, is shown in Figure 1. This cutoff point $(c)$, expressed as LnSCC, ranged from $0.27 \pm 0.89$ to $3.28 \pm$ 0.37 ( 1,300 to 26,600 cells $/ \mathrm{mL}$ ) for parity $1,1.98 \pm 0.24$ to $3.24 \pm 0.14$ (7,200 to 25,400 cells $/ \mathrm{mL})$ for parity 2 , and $2.39 \pm 0.15$ to $3.70 \pm 0.17$ (10,900 to 40,300 cells/ $\mathrm{mL}$ ) for parity 3 . Figures presented here suggest that no ML due to SCC (subclinical mastitis) occur prior to approximately LnSCC of $2.52 \pm 0.63$ (the average of all estimates of approximately 12,400 cells $/ \mathrm{mL}$ ).

\section{Regression on LnSCC}

The estimates of linear regression coefficient of daily milk yield on DIM were positive and had similar values across parities and stages of lactation. The mean value and standard deviation for the estimates were $0.0444 \pm$ $0.0021 \mathrm{~kg} / \mathrm{d}$ for parity $1 ; 0.0973 \pm 0.0051 \mathrm{~kg} / \mathrm{d}$ for parity 2 ; and $0.1078 \pm 0.0005 \mathrm{~kg} / \mathrm{d}$ for parity 3 . Weighted regressions using linear regression coefficients of each lactation as data points were all statistically significant, indicating that ML due to LnSCC vary across the lac- 


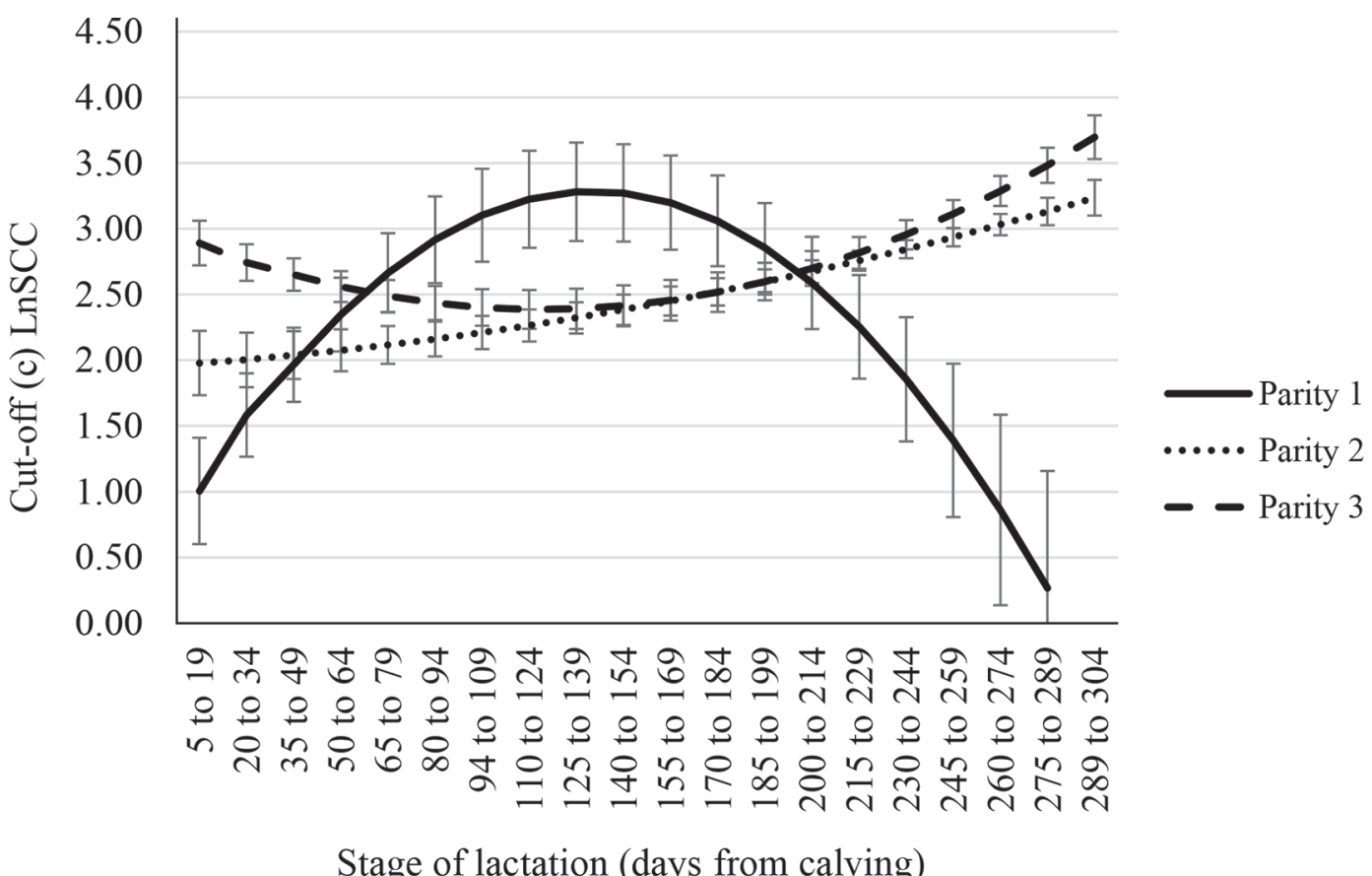

Figure 1. Estimates and SE of the cutoff point $(c)$ where milk losses associated with log-transformed [LnSCC; e.g., SCC $=100$ is equivalent to LnSCC of $4.61=100(\times 1,000)=100,000$ cells $/ \mathrm{mL}$ ] start for Holstein cows in Brazilian herds from 2010 to 2015 (parity $1=$ solid line; parity $2=$ dotted line; and parity $3=$ dashed line).

tation. Overall, ML associated with changes in LnSCC were not the same in different stages of the lactation and were lower in first parity than parity 2 and 3.

The linear regression coefficient of daily milk loss on LnSCC had estimates for first-lactation cows of approximately $0.68 \mathrm{~kg} / \mathrm{d}$ at the beginning of the lactation (5 to $19 \mathrm{DIM}$ ), $0.55 \mathrm{~kg} / \mathrm{d}$ at mid-lactation (110 to 124 DIM), and $0.97 \mathrm{~kg} / \mathrm{d}$ at the end of the lactation (289 to 304 DIM). For second-lactation cows, milk losses per unit increase of LnSCC had estimates around $1.47 \mathrm{~kg} / \mathrm{d}$ at the beginning of the lactation (5 to 19 DIM), 1.09

Table 3. Milk loss $\left(\mathrm{ML}^{1}\right)$ of parity 1 cows $^{2}$ for different levels of SCC

\begin{tabular}{ll}
\hline Level of SCC & ML \\
\hline 100,000 & 1.75 \\
200,000 & 2.21 \\
400,000 & 2.67 \\
500,000 & 2.81 \\
750,000 & 3.09
\end{tabular}

${ }^{1}$ Milk loss (ML), expressed as kg/cow per day.

${ }^{2}$ Parity 1 and stage 1 which corresponds to DIM 5 to 19 had threshold $(c)=1.01$. Parity 1 and stage 1 (d 5 to 19$)$ the expected milk loss (EML, b) was 0.68; SCC of 100,000 corresponds to LnSCC of 4.61. Thus, the ML from parity 1 and stage 1 corresponds to $(4.61-1.01)$ $\times 0.68=2.44 \mathrm{~kg} /$ cow per day. This can be done likewise for the other stages corresponding to parity 1 and then the average ML over these 20 stages $=1.75 \mathrm{~kg} /$ cow per d, and similarly for parity 2 and 3 . $\mathrm{kg} / \mathrm{d}$ at mid-lactation (110 to $124 \mathrm{DIM})$, and $2.45 \mathrm{~kg} / \mathrm{d}$ at the end of the lactation (289 to 304 DIM). For thirdlactation cows, milk losses per unit increase of LnSCC had estimates around $2.22 \mathrm{~kg} / \mathrm{d}$ at the beginning of the lactation (5 to $19 \mathrm{DIM}), 1.13 \mathrm{~kg} / \mathrm{d}$ at mid-lactation (140 to $154 \mathrm{DIM}$ ), and $2.65 \mathrm{~kg} / \mathrm{d}$ at the end of the lactation (289 to 304 DIM; Figure 2).

\section{Estimated Milk Losses}

The EML per unit increase of LnSCC according to parity-stage of lactation combination is provided in Table 4. Figure 3 (A, B and C) presents the predicted ML (\%) over the course of a full lactation, in parity 1 (Figure 3A), 2 (Figure 3B), and 3 (Figure 3C) cows according to the final model estimates based on the covariates investigated herein. By means of illustration, a first-lactation cow at 50 DIM and SCC 100,000 cells/ $\mathrm{mL}$ could be expected to have her milk production decreased by $0.94 \mathrm{~kg}[2.28-1.34 \mathrm{~kg}]$ if her SCC increase to 500,000 cells $/ \mathrm{mL}$ (see formula 1 and 2 below).

[1] Considering a first-lactation cow at 50 DIM with $\mathrm{SCC}=100,000$ cells $/ \mathrm{mL}$

$$
(4.61-2.35) \times 0.59=1.34
$$




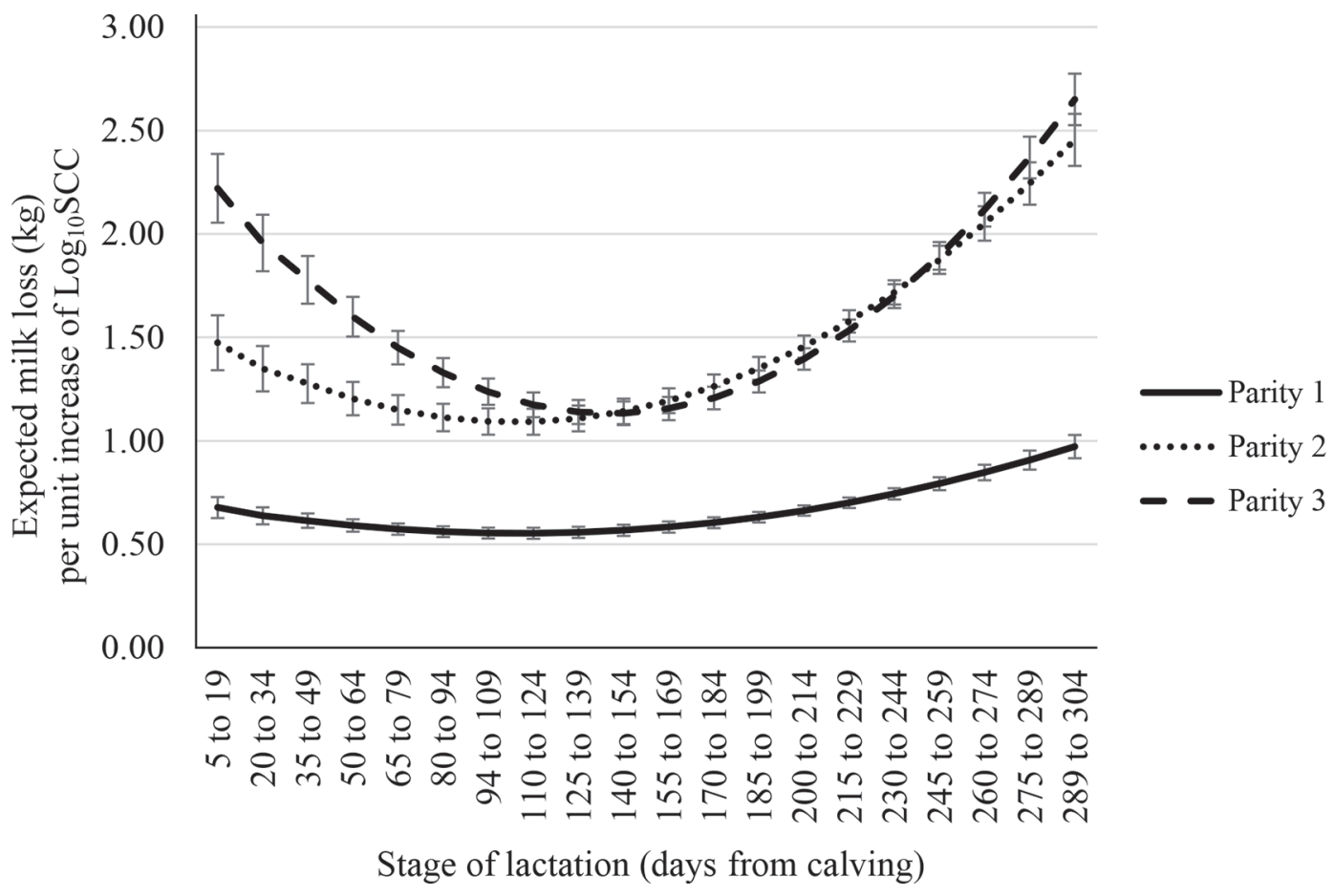

Figure 2. Estimates and SE of the linear regression coefficients of expected milk loss per unit increase in log-transformed SCC [LnSCC; e.g., $\mathrm{SCC}=100$ is equivalent to $\mathrm{LnSCC}$ of $4.61=100(\times 1,000)=100,000$ cells $/ \mathrm{mL}, b]$ for Holstein cows in Brazilian herds from 2010 to 2015 (Parity $1=$ solid line; parity $2=$ dotted line; and parity $3=$ dashed line).

Table 4. Effect $(\mathrm{kg})$ on daily milk yield of a unit change in $\operatorname{LnSCC}^{1}(\times 1,000$ cells $/ \mathrm{mL})$ from Holstein cows in parity 1,2 , and 3 at the stages of lactation

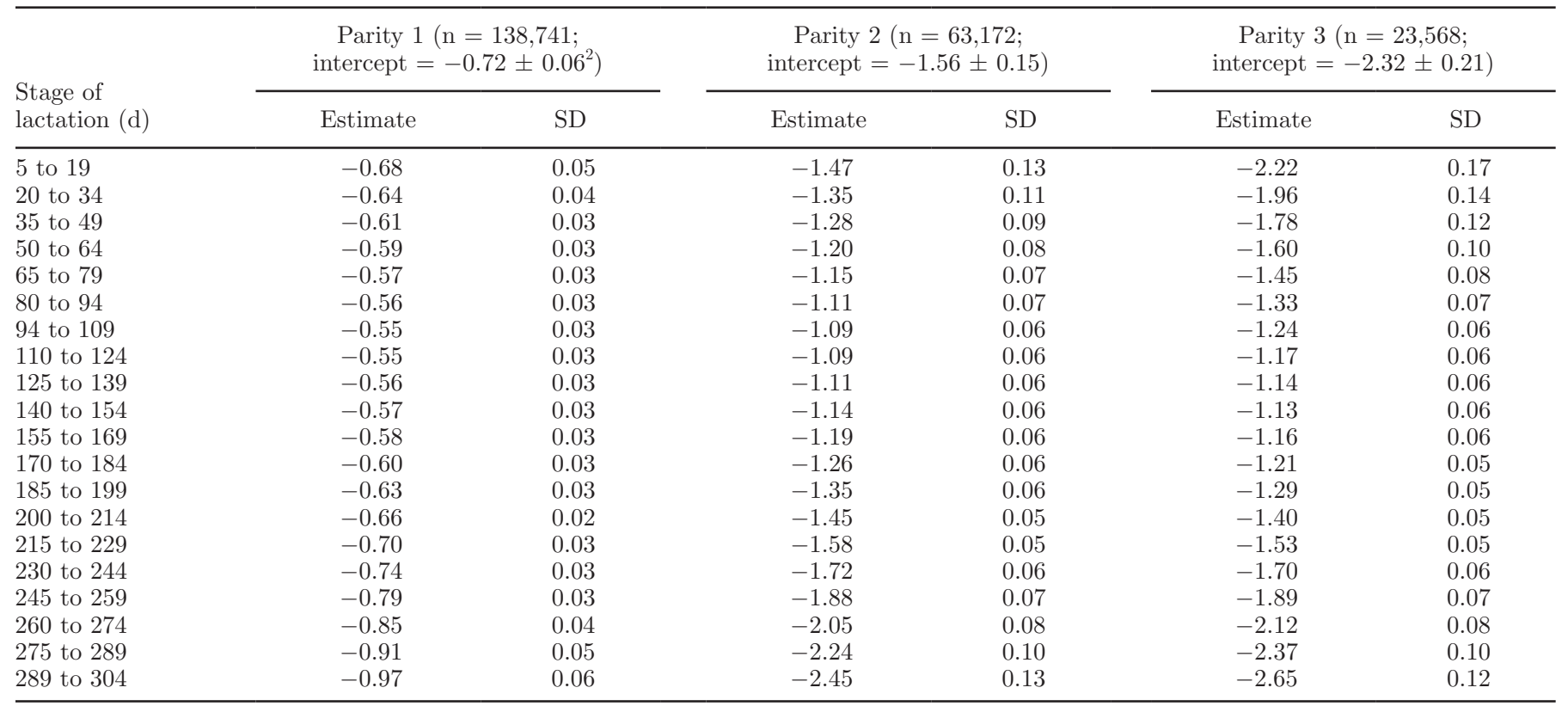

${ }^{1} \mathrm{SCC}=100$ is equivalent to $\mathrm{LnSCC}$ of $4.61=100(\times 1,000)=100,000$ cells $/ \mathrm{mL}$.

${ }^{2}$ The \pm values are SE. 


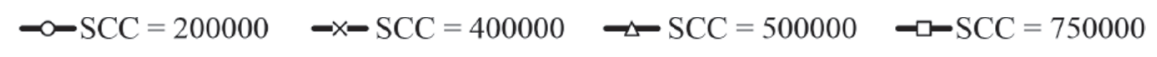

A)

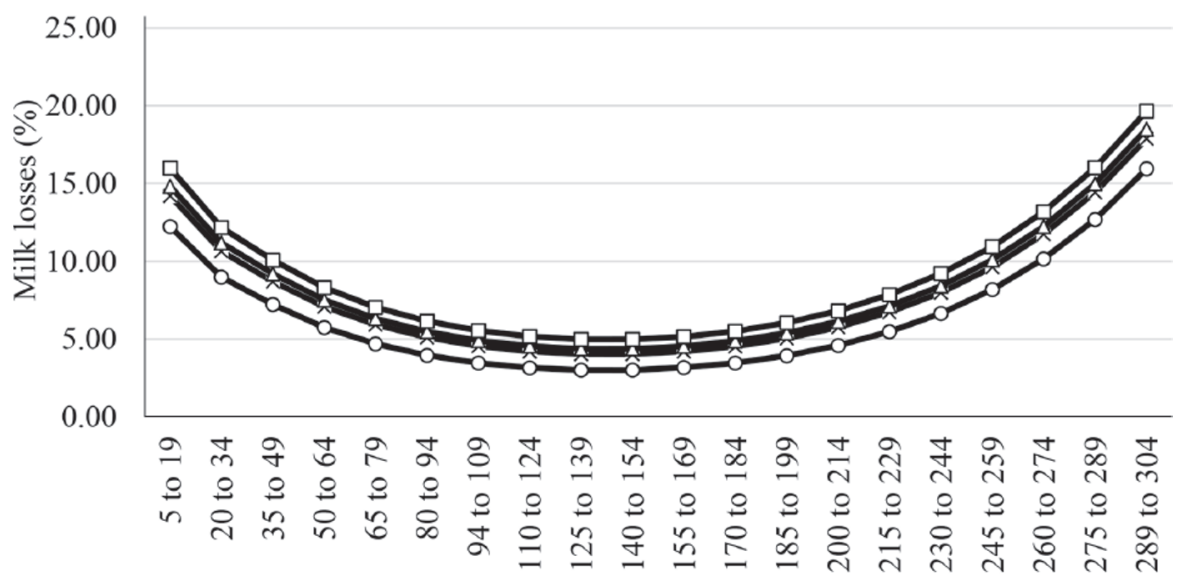

B)

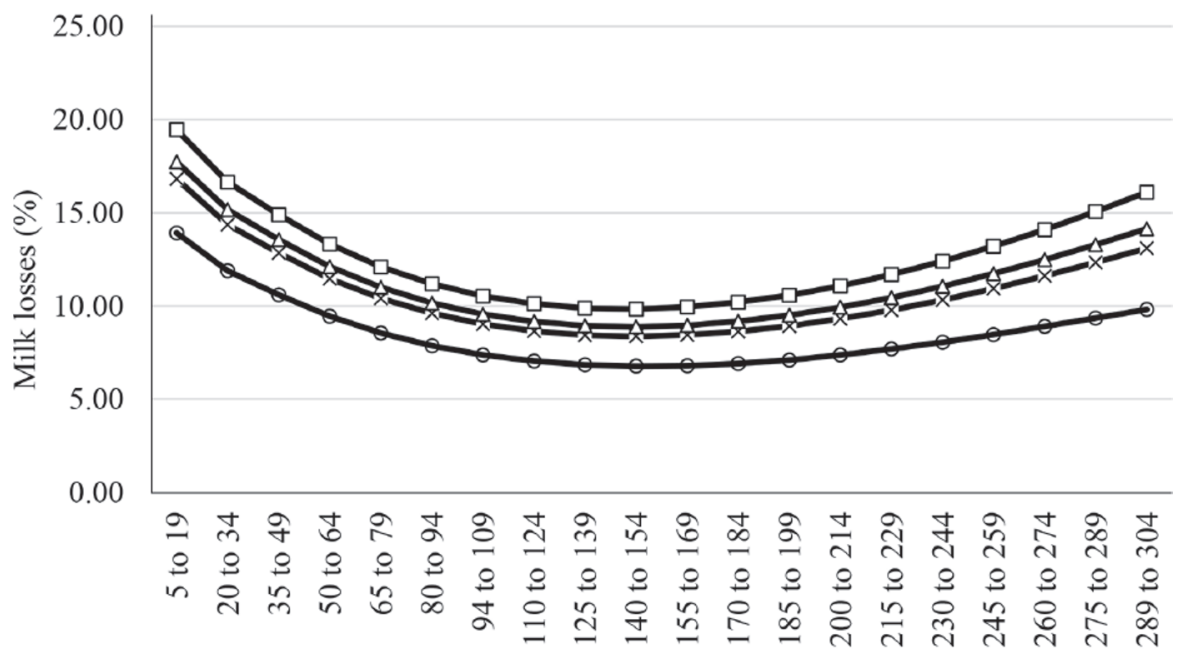

C)

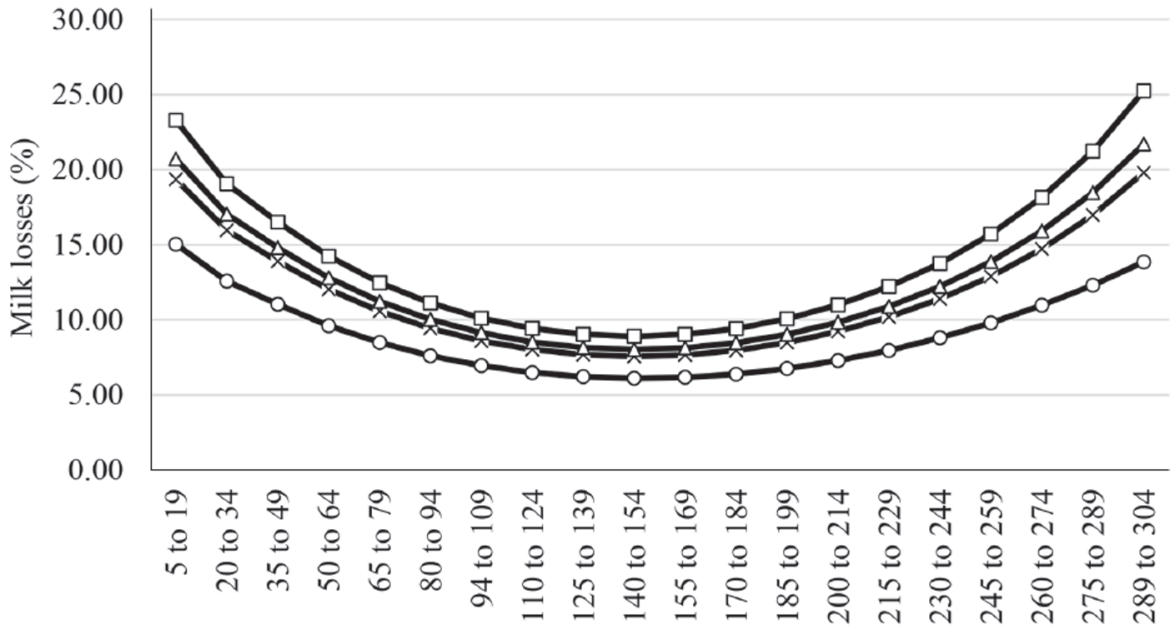

Stage of lactation (days from calving)

Figure 3. The daily milk loss (ML) for parity 1 (A), 2 (B), and 3 (C) distributed in different groups of SCC (cells/mL). 
[2] Considering a first-lactation cow at 50 DIM with $\mathrm{SCC}=500,000$ cells $/ \mathrm{mL}$

$$
(6.21-2.35) \times 0.59=2.28 .
$$

A visual comparison of both figures illustrates that losses in milk production due to increased LnSCC seem most severe among parities 2 and 3 .

\section{DISCUSSION}

The threshold of 200,000 cells/mL is generally regarded as the SCC cutoff level at which ML becomes evident at cow level (IDF, 2013). In our study, however, the association between SCC and milk production started to be evident at lower levels of SCC per milliliter (Figure 1), even among high-yielding cows (Coldebella et al., 2003). Recent models for milk yield and SCC estimations derived from lactation curves (Græsbøll et al., 2016) have demonstrated that the SCC per milliliter itself, recorded at test-day milk recording, is less correlated with milk production of healthy Danish Holsteins cows. It seems clear that parity and stage of lactation of the individual must be accounted for an accurate interpretation of its milk production. Our findings reinforce the role of these factors (Hand et al., 2012) on the relationship between the SCC and the milk recorded at test day from Brazilian Holsteins. Figures presented in the current study suggest that first-lactation Holstein cows at early stages of lactation (at d 5-19) may start experiencing ML at LnSCC $1.01 \pm 0.40$ cells/ $\mathrm{mL}$, whereas second- and third-lactation cows may have their milk production affected at LnSCC of 1.98 \pm 0.24 and $2.89 \pm 0.17$ cells $/ \mathrm{mL}$ at this stage $(5-19$ DIM), respectively. These results indicated that EML was more pronounced for second- and third-lactation cows $(1.47 \pm 0.13$ and $2.22 \pm 0.17 \mathrm{~kg} / \mathrm{d}$, respectively) than first-parity cows immediately after calving (0.68 $\mathrm{kg} / \mathrm{d} \pm 0.05)$ at the same stage of lactation with an increase of 1 unit point in natural logarithm of SCC (LnSCC) in the beginning of lactation. A similar trend across parity categories at the onset of lactation (d 1-15 from calving date) was observed by Dürr et al. (2008), who found these losses to be higher among adult cows $(0.88 \mathrm{~kg} / \mathrm{d})$ per unit increase of LnSCC than those experienced among primiparous $(0.49 \mathrm{~kg} / \mathrm{d})$ at the same stage of lactation. As mastitis-control measures within herds are more heavily adopted toward freshly calved primiparous cows (Miller et al., 2004), higher SCC is prone to occur among adult animals, possibly due to a decline in immune resistance as age progresses. The ML from first-parity animals at the onset of lactation that were identified herein was similar to that estimates from Archer et al. (2013), who found that a 1-unit increase in the LnSCC over the first 5 to $30 \mathrm{~d}$ after calving of first-lactation Irish dairy primiparous cows was associated with a median decrease of $0.44 \mathrm{~kg} / \mathrm{d}$ (our results approximately $0.64 \pm 0.04 \mathrm{~kg} / \mathrm{d}, 20$ to $34 \mathrm{DIM}$ ). Although those authors (Archer et al., 2013) accounted for the age of animals at calving in their model, they have not (or did not appear to have) taken the breed of animals into consideration for their analysis.

Estimated losses for each unit increase of LnSCC among mid-lactation cows were lower than those observed from early-lactation primiparous and adult cows. A 1-unit increase on LnSCC around 110 and 124 DIM of cows at first lactation was associated with an average milk decrease of $0.55 \pm 0.03 \mathrm{~kg} / \mathrm{d}$, and of $0.97 \pm 0.06$ $\mathrm{kg} / \mathrm{d}$ for cows at later lactation (at d 289-304). The decrease in milk production estimated by our study was similar than that reported by Dürr et al. (2008) for Holstein cows at about the same stage of lactation. Losses observed at d 121 of lactation by Dürr et al. (2008) for primiparous were 0.34 and $0.81 \mathrm{~kg} / \mathrm{d}$ in adult cows with the increase in the LnSCC of 1 unit. Importantly, mid-lactation dairy cows (at 101-200 DIM) from southern herds in Brazil are at increased risk of occurrence of chronic cases of subclinical mastitis compared with animals at 100 DIM (Cardozo et al., 2015), which could also explain the increased estimates of ML found in our study and the LnSCC cutoff point associated with it.

The cutoff LnSCC at which second- and third-lactation cows started experiencing ML was identified during the first stage of lactation $(1.98 \pm 0.24$ and $2.89 \pm$ 0.17 cells $/ \mathrm{mL}$ at $\mathrm{d} 5-19$, respectively). This is biologically plausible, as cows are in negative energy balance and udder defenses may be impaired due to metabolic stress (Hagnestam-Nielsen et al., 2009). Among the primiparous cows, the lowest cutoff LnSCC was observed as lactation progressed toward its end (275-289 DIM; LnSCC $0.27 \pm 0.89$ cells $/ \mathrm{mL}$ ). However, an opposite trend has been reported, higher SCC cutoff points in the beginning of the lactation for first lactation cows, by Dürr et al. (2008), as they observed a decrease of SCC cutoff points at 136 to $150 \mathrm{~d}$ that remained similar until the end of lactation (at 286-300 d).

Findings reported here substantiate the SCC level, parity, and the stage of lactation at which ML are expected to be a matter of concern to the Brazilian dairy farmer. Previous studies addressed the issue by showing ML around 0.61 and $3.26 \mathrm{~kg} / \mathrm{d}$ from primiparous and multiparous cows, respectively, with the increase of individual test-day SCC at a cutoff from 14,270 cells/ mL (Coldebella et al., 2003). However, the use of those 
results may be of limited application given the diversity of herd management nationwide, as their findings were based on a single herd with well-managed on-farm practices in place (Coldebella et al., 2003). Figures presented in the current study corroborate their estimates (Coldebella et al., 2003), but may apply more broadly to the entire Brazilian dairy industry, as they depict a typical proportion of the Holstein breed population in the country. The average SCC at which cows began to underperform was estimated approximately at 12,400 cells $/ \mathrm{mL}$. Over this threshold, however, our estimates of ML per an increase of 1 unit in LnSCC were higher by, on average, $0.67 \pm 0.03,1.46 \pm 0.08$, and $1.62 \pm$ $0.08 \mathrm{~kg} / \mathrm{d}$, for first-, second-, and third-lactation Brazilian Holstein cows, respectively. This implies that ML across the Brazilian Holstein population used in our study (where currently $16 \%$ of all test-day records have SCC >200,000 cells $/ \mathrm{mL}$ ) would be greater than $6.5 \%$ for primiparous, $8.5 \%$ for second lactation, and $9 \%$ for third lactation cows [Figure $3 \mathrm{~A}, \mathrm{~B}$, and $\mathrm{C}$; note, $6.5 \%$ corresponds to the average of the percentage losses expected for SCC 200,000 cells/mL for each stage of lactation (stages 1 to 20) for parity 1 cows (Figure 3A, $\mathrm{SCC}=200,000$ ) and likewise from Figure $3 \mathrm{~B}$ (parity 2) and Figure 3C (parity 3 ) $\mathrm{SCC}=200,000$ ]. Given the concerns around the SCC at cow level and its economic implication, especially on levels at which ML is still overlooked by the dairy farmer, implementation of mastitis-control strategies at a herd level has to be defined by understanding what acceptable level of associated losses with the bulk tank SCC is aimed for by the dairy farmer (Troendle et al., 2017). This understanding, therefore, may be pivotal for the successful implementation of such programs and assist the dairy industry to accurately estimate losses associated with SCC, especially at cow level.

\section{CONCLUSIONS}

Daily milk losses caused by changes in LnSCC were dependent on parity and stage of lactation, and these factors should be considered when evaluating individual SCC. Lactation milk loss $(\mathrm{kg})$ increased significantly as lactation-average SCC increased. Milk yield starts to be affected by changes in LnSCC only after a cutoff point, which is about 2.52 (the average of all estimates of approximately 12,400 cells $/ \mathrm{mL}$ ) for Holsteins cows from Brazilian herds. Second- and third-lactation cows had greater milk loss than did primiparous cows. Milk losses per unit increase in LnSCC varied from 0.55 to $0.97 \mathrm{~kg} / \mathrm{d}$ in first lactation, 1.09 to $2.45 \mathrm{~kg} / \mathrm{d}$ in second lactation, and 1.13 to $2.65 \mathrm{~kg} / \mathrm{d}$ in third lactation. The milk losses were smaller during the lactation peak.

\section{ACKNOWLEDGMENTS}

The authors acknowledge São Paulo Research Foundation (FAPESP, São Paulo, SP, Brazil) for the scholarship (Proc. 2013/23613-8 and 2015/04570-1) and project funding (Proc. 2014/17411-6), and Associação Paranaense de Criadores de Bovinos da Raça Holandesa (APCBRH, Curitiba, PR, Brazil) for providing the data for this study.

\section{REFERENCES}

Archer, S. C., F. Mc Coy, W. Wapenaar, and M. J. Green. 2013. Association between somatic cell count early in the first lactation and the lifetime milk yield of cows in Irish dairy herds. J. Dairy Sci. 96:2951-2959.

Boland, F., L. O'Grady, and S. J. More. 2013. Investigating a dilution effect between somatic cell count and milk yield and estimating milk production losses in Irish dairy cattle. J. Dairy Sci. 96:1477-1484.

Bradley, A., and M. Green. 2005. Use and interpretation of somatic cell count data in dairy cows. In Pract. 27:310-315.

Capuco, A. V., S. E. Ellis, S. A. Hale, E. Long, R. A. Erdman, X. Zhao, and M. J. Paape. 2003. Lactation persistency: Insights from mammary cell proliferation studies. J. Anim. Sci. 81(Suppl 3):18-31.

Cardozo, L. L., A. Thaler Neto, G. N. Souza, L. C. A. Picinin, N. C. Felipus, N. L. M. Reche, F. A. Schmidt, D. Werncke, and E. E. Simon. 2015. Risk factors for the occurrence of new and chronic cases of subclinical mastitis in dairy herds in southern Brazil. J. Dairy Sci. 98:7675-7685.

Coldebella, A., P. F. Machado, C. G. B. Demétrio, P. J. Ribeiro Júnior, C. H. Corassin, P. M. Meyer, and L. D. Cassoli. 2003. Contagem de células somáticas e produção de leite em vacas holandesas de alta produção. Pesqui. Agropecu. Bras. 38:1451-1457.

Cunha, R. P. L., L. R. Molina, A. U. Carvalho, E. J. Facury Filho, P. M. Ferreira, and M. B. Gentilini. 2008. Mastite subclínica e relação da contagem de células somáticas com número de lactações, produção e composição química do leite em vacas da raça Holandesa. Arq. Bras. Med. Vet. Zootec. 60:19-24.

Dürr, J. W., R. I. Cue, H. G. Monardes, J. Moro-Méndez, and K. M. Wade. 2008. Milk losses associated with somatic cell counts per breed, parity and stage of lactation in Canadian dairy cattle. Livest. Sci. 117:225-232.

Geary, U., N. Lopez-Villalobos, N. Begley, F. McCoy, B. O'Brien, L. O'Grady, and L. Shalloo. 2012. Estimating the effect of mastitis on the profitability of Irish dairy farms. J. Dairy Sci. 95:3662-3673.

Græsbøll, K., C. Kirkeby, S. S. Nielsen, T. Halasa, N. Toft, and L. E. Christiansen. 2016. Models to estimate lactation curves of milk yield and somatic cell count in dairy cows at the herd level for the use in simulations and predictive models. Front. Vet. Sci. 3:115.

Green, L. E., Y. H. Schukken, and M. J. Green. 2006. On distinguishing cause and consequence: Do high somatic cell counts lead to lower milk yield or does high milk yield lead to lower somatic cell count? Prev. Vet. Med. 76:74-89.

Hagnestam-Nielsen, C., U. Emanuelson, B. Berglund, and E. Strandberg. 2009. Relationship between somatic cell count and milk yield in different stages of lactation. J. Dairy Sci. 92:3124-3133.

Halasa, T., K. Huijps, O. Osteras, and H. Hogeveen. 2007. Economic effects of bovine mastitis and mastitis management: a review. Vet. Q. 29:18-31.

Halasa, T., M. Nielen, A. P. De Roos, R. Van Hoorne, G. de Jong, T. J. Lam, T. van Werven, and H. Hogeveen. 2009. Production loss due to new subclinical mastitis in Dutch dairy cows estimated with a test-day model. J. Dairy Sci. 92:599-606.

Hand, K. J., A. Godkin, and D. F. Kelton. 2012. Milk production and somatic cell counts: a cow-level analysis. J. Dairy Sci. 95:13581362 . 
Hogeveen, H., K. Huijps, and T. J. Lam. 2011. Economic aspects of mastitis: New developments. N. Z. Vet. J. 59:16-23.

Hortet, P., and H. Seegers. 1998. Calculated milk production losses associated with elevated somatic cell counts in dairy cows: review and critical discussion. Vet. Res. 29:497-510.

Huijps, K., T. J. Lam, and H. Hogeveen. 2008. Costs of mastitis: facts and perception. J. Dairy Res. 75:113-120.

International Dairy Federation. 2013. Guidelines for the use and interpretation of bovine milk somatic cell counts (SCC) in the dairy industry. Bulletin of the International Dairy Federation. 466/2013. IDF, Brussels, Belgium.

Miller, R. H., H. D. Norman, G. R. Wiggans, and J. R. Wright. 2004. Relationship of test-day somatic cell score with test-day and lactation milk yields. J. Dairy Sci. 87:2299-2306.
Schukken, Y. H., D. J. Wilson, F. Welcome, L. Garrison-Tikofsky, and R. N. Gonzalez. 2003. Monitoring udder health and milk quality using somatic cell counts. Vet. Res. 34:579-596.

Seegers, H., C. Fourichon, and F. Beaudeau. 2003. Production effects related to mastitis and mastitis economics in dairy cattle herds. Vet. Res. 34:475-491.

Troendle, J. A., L. W. Tauer, and Y. T. Gröhn. 2017. Optimally achieving milk bulk tank somatic cell count thresholds. J. Dairy Sci. 100:731-738.

van Asseldonk, M. A., R. J. Renes, T. J. Lam, and H. Hogeveen. 2010. Awareness and perceived value of economic information in controlling somatic cell count. Vet. Rec. 166:263-267. 